\title{
Nursing diagnoses in a home-based program: cross-mapping and NANDA-I Taxonomy
}

\author{
Diagnósticos de enfermagem em programa domiciliar: mapeamento cruzado e Taxonomia da NANDA-I \\ Diagnósticos de enfermería en un programa domiciliar: mapeo cruzado y Taxonomía de la NANDA-I
}

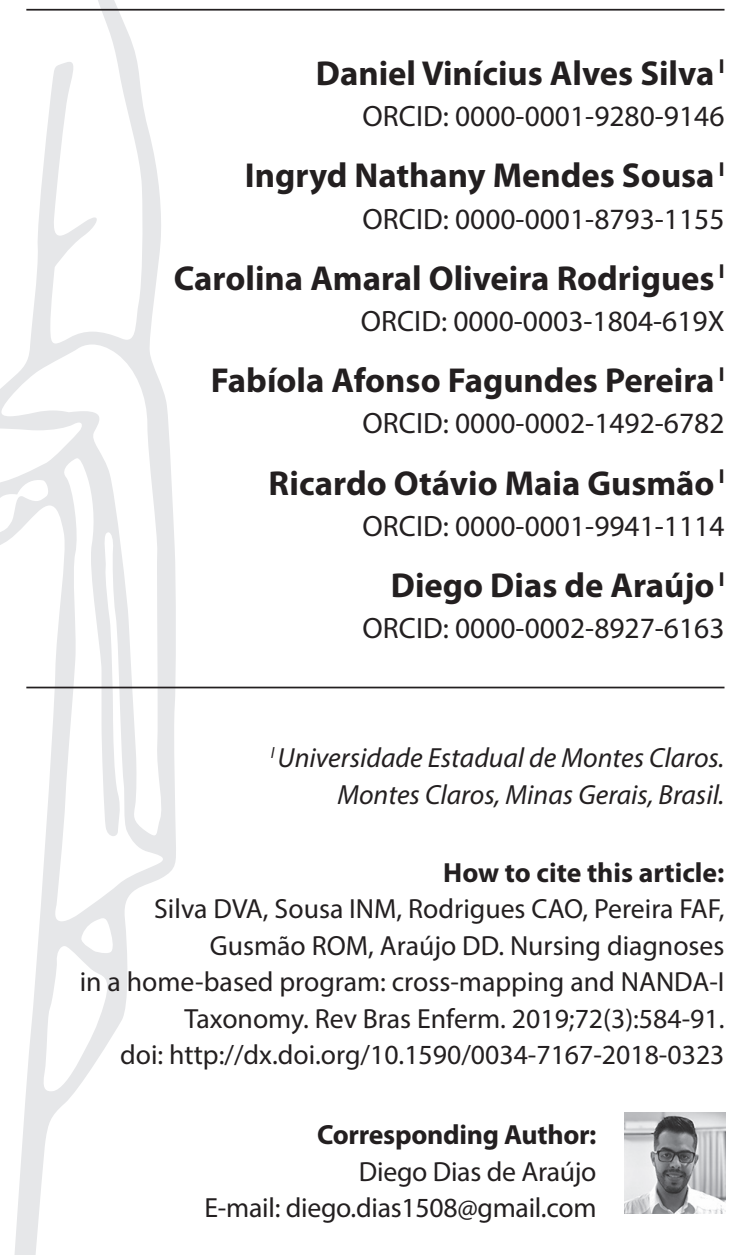

Submission: 05-10-2018 Approval: 01-23-2019

\begin{abstract}
Objective: to identify Nursing diagnoses in patients in home care by cross-mapping terms obtained in the anamnesis and clinical examination, with NANDA-I Taxonomy. Method: descriptive exploratory study, transversal type, performed with 131 patients from a home health care program in northern Minas Gerais State. With the aid of an instrument based on the theoretical model of Basic Human Needs, the terms indicators of conditions that required nursing interventions were extracted. The cross-mapping of these terms was also performed with NANDA-I Taxonomy diagnoses. Results: 378 terms and expressions referring to 49 different diagnoses were identified in 11 of the 13 domains of NANDA-I Taxonomy. Conclusion: the profile of identified nursing diagnoses can contribute to care management and organizational processes of nurses who provide care to patients in home care.

Descriptors: Home-care Patients; Homecare Services; Nursing; Nursing Diagnosis; Nursing Process.
\end{abstract}

\section{RESUMO}

Objetivo: identificar diagnósticos de enfermagem em pacientes em atenção domiciliar por meio do mapeamento cruzado de termos obtidos na anamnese e o exame clínico, com a Taxonomia da NANDA-I. Método: estudo exploratório descritivo, do tipo transversal realizado com 131 pacientes de um programa de atenção domiciliar à saúde do norte de Minas Gerais. Com o auxílio de um instrumento embasado no modelo teórico das Necessidades Humanas Básicas extraíram-se os termos indicadores de condições que demandavam intervenções de enfermagem. Realizou-se, também, o mapeamento cruzado desses termos com os diagnósticos da Taxonomia da NANDA-I. Resultados: foram identificados 378 termos e expressões que se referiam a 49 diferentes diagnósticos em 11 dos 13 domínios da Taxonomia da NANDA-I. Conclusão: o perfil de diagnósticos de enfermagem identificado pode contribuir para a gestão do cuidado e dos processos organizacionais de enfermeiros que prestam assistência a pacientes em atenção domiciliar.

Descritores: Pacientes Domiciliares; Serviços de Assistência Domiciliar; Enfermagem; Diagnóstico de Enfermagem; Processo de Enfermagem.

\section{RESUMEN}

Objetivo: identificar diagnósticos de enfermería en pacientes en atención domiciliaria por medio del mapeo cruzado de términos obtenidos en la anamnesis y el examen clínico, con la Taxonomía de la NANDA-I. Método: estudio exploratorio descriptivo, del tipo transversal, realizado con 131 pacientes de un programa de atención domiciliaria de salud del norte del estado de Minas Gerais. Con el auxilio de un instrumento basado en el modelo teórico de las Necesidades Humanas Básicas se extrajeron los términos indicadores de condiciones que demandaban intervenciones de enfermería. Se realizó, también, el mapeo cruzado de esos términos con los diagnósticos de la Taxonomía de la NANDA-I. Resultados: se identificaron 378 términos y expresiones que se referían a 49 diferentes diagnósticos en 11 de los 13 dominios de la Taxonomía de la NANDA-I. Conclusión: el perfil de diagnósticos de enfermería identificado puede contribuir a la gestión de la atención y de los procesos organizacionales de enfermeros que prestan asistencia a pacientes en atención domiciliaria.

Descriptores: Personas Imposibilitadas; Servicios de Atención de Salud a Domicilio; Enfermería; Diagnóstico de Enfermería; Proceso de Enfermería. 


\section{INTRODUCTION}

Home care $(\mathrm{HC})$ is defined as a form of care at home, characterized by developing actions to promote health, prevent injuries, treat, palliate or rehabilitate health conditions. Its purpose is to increase the autonomy of users, families and caregivers, helping to optimize hospital beds, reduction of costs and reintegration of patient into their family and support nuclei ${ }^{(1)}$.

This type of care is indicated for patients who are temporarily or permanently restricted to their bed or their home. In HC, dementia and frailty, cerebrovascular accidents, cardiocirculatory, respiratory and musculoskeletal syndromes, sequelae of traffic accidents and violence ${ }^{(1)}$ stand out among the indications.

Among the professionals who make up the multiprofessional health team, which provides care to HC patients, nurses stand out. These professionals perform fundamental functions both for coordinating the care plan and for the bond that they establish with patients, their families and caregivers; nurses are indispensable for the adhesion and execution of the actions to be performed ${ }^{(2)}$.

One way to provide the $\mathrm{HC}$ patients with quality and organized nursing care is through the Systematization of Nursing Care (SNC). For this, the implementation of the Nursing Process (NP) must occur previously. It is the clinical method of the profession that guides nursing care and is composed of data collection, nursing diagnosis (ND), planning, implementation and nursing evaluation steps $^{(3)}$. Nursing taxonomies and standardized languages can be used to designate ND, interventions and nursing outcomes.

NANDA International Inc. (NANDA-I) is a consolidated reference for the classification of ND and defines it as the "clinical judgment regarding an undesirable human response to a health condition/ life process that exists in a person, family, group or community"(4). Its formulation directly impacts the organization and effectiveness of care; it is the basis for the selection and implementation of nursing interventions, with a view to clinical and risk control.

The identification of the ND profile incorporated into a standardized language contributes to the management of resources and people, besides subsidizing nursing interventions. It favors the permanent education and the strengthening of the professional identity, by defining which scientific phenomena are of Nursing domain ${ }^{(5)}$.

It should be emphasized that adherence to SNC and implementation of the NP are legally established and fundamental measures for Nursing. In addition, there is a shortage in the national and international scientific production on the subject at hand.

\section{OBJECTIVE}

To identify Nursing diagnoses in patients in home care by cross-mapping terms obtained in the anamnesis and clinical examination, with NANDA-I Taxonomy.

\section{METHOD}

\section{Ethical aspects}

The present study was approved by the Research Ethics Committee of the State University of Montes Claros (UNIMONTES).

\section{Research design, place and period}

Exploratory descriptive study, of the cross-sectional type, based on terms obtained in the nursing consultation, with the aid of an instrument, performed with registered patients and attended by a home health care program in the north of Minas Gerais State, Brazil, between June 2017 and January 2018. This period was necessary to conduct the nursing consultation for all patients enrolled and included in the program. It is emphasized that the service does not use a standard ND language.

The program in question has four HC multiprofessional teams, and counts with physicians, nurses, physiotherapists and Nursing technicians, as well as two multiprofessional support teams, integrated by speech therapists, physiotherapists, nutritionists and psychologists.

\section{Population, inclusion and exclusion criteria}

Patients who met the following inclusion criteria were included: being 18 or older, being enrolled and attending the $\mathrm{HC}$ program and consenting to participate in the study or having their participation authorized by their caregivers, by signing the Free and Informed Consent Form (ICF). The exclusion criteria were: not being found at home in up to three attempts, evolving to death before data collection is performed and being hospitalized.

At the data collection period, there were 172 patients enrolled and under care. Of the population, ten were excluded because they were underage; seven because they were not found at home in up to three attempts; six due to hospitalization; five did not agree to participate in the study; and thirteen evolved to death before data collection was performed. Thus, after applying the inclusion and exclusion criteria, a total of 131 patients were included in the sample.

\section{Study protocol}

The data collection procedure was performed by a Nursing graduate of the seventh semester of the Nursing undergraduate course at a public university in the state of Minas Gerais, duly trained and supervised by his advisory teacher. Training consisted of theoretical explanation about anamnesis and clinical examination, practical training, besides reading articles and texts on the subject.

For data collection, anamnesis and clinical examination of patients were carried out in their homes. Data collection took an average of 1 hour and 30 minutes. A systematized instrument was developed, based on a literature review ${ }^{(6-9)}$, containing sociodemographic and clinical characterization variables. It is noteworthy that the selection process of the instrument of data collection occurred, through the appreciation of specialists who evaluated its quality and relevance, and all the suggested changes were adhered to and the final instrument was consolidated by consensus.

The data collection instrument was conceived according to the conceptual model of Wanda Aguiar Horta ${ }^{(10)}$, following the theoretical model Maslow's hierarchy of needs as the guiding principle. This instrument was organized to include the following topics: 
I. Identification data and health history: sex, age, marital status, skin color, family income, schooling, profession and occupation, medical history, any current complaints, medical diagnoses, history of use of drugs, habits and lifestyle.

II. Objective and subjective data related to the hierarchy of needs:

- Psycho-spiritual needs: religious belief, spiritual need, maintenance of habits;

- Psychosocial needs: communication, social interaction, family relationship, leisure time/recreation, self-esteem, self-realization, safety, learning (knowledge about illness and treatment) and space (basic sanitation, water supply and treatment, electricity and the number of people living at home);

- Psychobiological needs: neurological regulation, sleep/ rest, sensory perception, thermoregulation, general appearance, body care, nutrition/hydration, oxygenation/ respiration, vascular regulation/circulation, abdominal examination, elimination, sexuality, physical activity/ mobility, tissue integrity.

Later, cross-mapping of the identified terms was performed, determining the diagnoses established by NANDA-I classification ${ }^{(4)}$, considering its components (title, related factors, defining characteristics and risk factors).

Cross-mapping is a process performed to identify terms that allow us to explain or express something by using words with the same or similar meaning. These terms can be used, compared or understood from a standardized language, making it feasible to compare different nursing classifications ${ }^{(5,11)}$.

The rules established for the cross-mapping in the study were as follows: 1 ) map using the taxonomy of NANDA-I NDs, $2015 / 2017$ edition; 2) seek to ensure the meaning of terms and expressions identified from the anamnesis and clinical examination; 3 ) correlate the terms and standardized expressions to the diagnostic focuses; 4 ) establish a relation between the terms and standardized expressions that refer to the diagnostic focuses existing in the diagnostic concepts; 5) correlate standardized terms and expressions with diagnostic definitions, defining characteristics, related factors, and risk factors of diagnostic concepts (which encompassed the primarily identified diagnostic focuses); 6) indicate and specify the possible concepts of NDs; and 7) map possible NDs within NANDA-I domains, 2015/2017 edition $^{(5,12)}$.

\section{Results analysis and statistics}

Data were entered in an electronic worksheet Microsoft Excel 2013 and a descriptive analysis was performed (simple and percentage frequency).

\section{RESULTS}

Among the 131 patients, 72 (55\%) were female. Age range ranged from 20 to 110 years old. Mean age was 66.8 and median, 72 . The main medical diagnoses identified in the individuals enrolled and in the home care program were categorized into circulatory system diseases (42\%), neurological 36 (27.5\%) and metabolic 26 (19.8\%) ones.

Based on the analysis, 4,306 terms were identified as indicators of human responses that required nursing interventions: dysfunctions, health conditions, life processes, motivation to increase one's wellbeing and conditions of vulnerability presented by patients. After excluding repetitions, 378 terms and expressions that compose the database of this study were obtained.

NANDA-I ${ }^{(4)}$ has 234 NDs distributed in 13 domains of human responses. With cross-mapping, 2,508 NDs titles were established for 131 patients, with an average of 19.1 diagnoses per patient. After excluding repetitions, 49 different NDs titles were found. Of these, $36(73.5 \%)$ refer to real NDs and $13(26.5 \%)$ to risk diagnosis titles. They are distributed in eleven of the thirteen NANDA-I taxonomy domains, and no diagnostic titles were identified in the domains 8. Sexuality and 13. Growth/Development (Table 1).

The most frequent NDs (present in at least $60 \%$ of patients) were: impaired physical mobility (00085) ( $n=115 ; 87.8 \%)$; self-care deficit for feeding (00102) ( $n=112 ; 85.5 \%)$; self-care deficit for dressing (00109) $(n=112 ; 85.5 \%)$; self-care deficit for bathing (00108) $(n=109 ; 83.2 \%)$; risk of poor fluid volume $(00028)(n=109 ; 83.2 \%)$; risk of electrolyte imbalance (00195) ( $n=106 ; 80.9 \%)$; risk of disuse syndrome $(00040)$ $(n=105 ; 80.1 \%)$; risk of pressure ulcers $(00249)(n=104 ; 79.4 \%)$; deficit in self-care for intimate hygiene $(00110)(n=97 ; 74.0 \%)$; impaired transfer capacity (00090) $(n=96 ; 73.3 \%)$; impaired social interaction (00052) ( $n=94 ; 71.7 \%)$; impaired mobility in bed (00091) ( $n=88 ; 67.2 \%)$; impaired urinary elimination (00016) $(n=87 ; 66.4 \%)$; impaired verbal communication (00051) ( $n=82 ; 62.6 \%)$.

Table 2 presents the defining characteristics and related factors of the most frequent real NDs titles (present in at least $60 \%$ of the patients), identified in mapping.

Table 3 presents the risk factors of the most frequent risk NDs titles (present in more than $60 \%$ of patients), identified in mapping.

Table 1 - Distribution of nursing diagnosis titles identified in patients $(n=131)$ in home care, according to NANDA-I domains, Montes Claros City, Minas Gerais State, Brazil, June 2017 to January 2018

\begin{tabular}{llc}
\hline Domain & Diagnostic nursing titles (code) & $\mathbf{n}(\%)$ \\
\hline 1. Health Promotion & & $27(20.6)$ \\
& Sedentary lifestyle (00168) & $1(0.8)$ \\
& Low adhesion (00079) & $66(50.4)$ \\
$6(4.6)$ & $49(37.4)$ \\
2. Nutrition & The Frailty Syndrome (00257) & $106(80.9)$ \\
& Risk of having the frailty syndrome (00231) & $109(83.2)$ \\
\hline & Unbalanced nutrition: less than the bodily needs (00002) & Tisk of electrolyte imbalance (00195) \\
& Risk of poor volume of liquids (00028) continued
\end{tabular}


Domain

3. Elimination and Changing

4. Activity/Rest

5. Perception/Cognition

6. Self-perception

7. Roles and Relationships

9. Confrontation/ Stress tolerance

10. Life Principles

11. Safety/ Protection

12. Comfort
Diagnostic nursing titles (code)

n (\%)

Constipation (00011)

Diarrhea (00013)

Impaired urinary elimination (00016)

Bowel incontinence (00014)

Functional urinary incontinence (00020)

Risk of constipation (00015)

$21(16.0)$

$1(0.8)$

$87(66.4)$

$73(55.7)$

$13(9.9)$

$67(51.1)$

Impaired transfer capacity (00090)

$96(73.3)$

$20(15.3)$

Impaired walking (00088)

Self-care deficit for feeding (00102)

Self-care deficit for bathing (00108)

Self-care deficit for intimate hygiene (00110)

Self-care deficit for dressing (00109)

Insomnia (00095)

Intolerance to activity $(00092$

Impaired physical mobility (00085)

Impaired mobility in bed (00091)

Ineffective respiratory pattern (00032)

Ineffective peripheral tissue perfusion (00204)

Risk of impaired cardiovascular function (00239)

Risk of disuse syndrome (00040)

$112(85.5)$

$109(83.2)$

$97(74.0)$

$112(85.5)$

$64(48.5)$

$4(3.0)$

$115(87.8)$

$87(66.4)$

$26(19.8)$

$37(28.2)$

$8(6.1)$

$105(80.1)$

Impaired verbal communication (00051)

$82(62.6)$

Chronic confusion (00129)

Poor knowledge (00126)

Impaired memory (00131)

$13(9.9)$

$28(21.4)$

$78(59.5)$

$3(2.3)$

Despair (00124)

$22(16.8)$

Impaired social interaction (00052)

Interrupted family processes (00060)

94 (71.7)

$21(16.0)$

Chronic sadness (00137)

$1(0.8)$

$1(0.8)$

$47(35.9)$

Provision for improved decision making (00184)

$4(3.0)$

Hypothermia (00006)

Impaired skin integrity (00046)

$72(55.0)$

$76(58.0)$

$78(59.5)$

Risk of infection (00004)

Risk of impaired skin integrity (00047)

$40(30.5)$

$1(0.8)$

Risk of dry eyes (00219)

$58(44.3)$

$104(79.4)$

Risk of pressure ulcers (00249)

$5(3.8)$

$45(34.3)$

$17(13.0)$

Table 2 - Distribution of the defining characteristics and related factors of the most frequent real nursing diagnoses, identified in patients ( $\mathrm{n}=131)$ in home care, according to NANDA-I taxonomy domains, Montes Claros City, Minas Gerais State, Brazil, from June 2017 to January 2018

\begin{tabular}{|c|c|c|c|c|}
\hline $\begin{array}{l}\text { Domain/ } \\
\text { Diagnosis } \\
\text { (code) }\end{array}$ & Defining characteristics & n (\%) & Related factors & n (\%) \\
\hline $\begin{array}{l}\text { D3/Impaired } \\
\text { urinary } \\
\text { elimination } \\
(00016)\end{array}$ & $\begin{array}{l}\text { Dysuria } \\
\text { Frequency } \\
\text { Urinary incontinence } \\
\text { Nocturia } \\
\text { Urinary retention }\end{array}$ & $\begin{aligned} 3 & (2.3) \\
7 & (5.3) \\
81 & (61.8) \\
2 & (1.5) \\
2 & (1.5)\end{aligned}$ & $\begin{array}{l}\text { Sensory motor deficits } \\
\text { Multiple causes } \\
\text { Urinary tract infection }\end{array}$ & $\begin{array}{c}3(2.3) \\
85(64.9) \\
1(0.8)\end{array}$ \\
\hline $\begin{array}{l}\text { D4/Impaired } \\
\text { transfer } \\
\text { capacity } \\
(00090)\end{array}$ & Impaired ability to move from bed to chair & $96(73.3)$ & $\begin{array}{l}\text { Change in cognitive functions } \\
\text { Pain } \\
\text { Musculoskeletal disorders } \\
\text { Neuromuscular diseases }\end{array}$ & $\begin{array}{l}68(51.9) \\
20(15.3) \\
16(12.2) \\
60(45.8)\end{array}$ \\
\hline $\begin{array}{l}\text { D4/Self-care } \\
\text { deficit for } \\
\text { feeding (00102) }\end{array}$ & $\begin{array}{l}\text { Impaired ability to eat in an acceptable way } \\
\text { Impaired ability to prepare food }\end{array}$ & $\begin{array}{l}79(60.3) \\
33(25.2)\end{array}$ & $\begin{array}{l}\text { Change in cognitive functions } \\
\text { Discomfort } \\
\text { Perceptual disorders } \\
\text { Pain } \\
\text { Musculoskeletal disorders } \\
\text { Neuromuscular diseases }\end{array}$ & $\begin{array}{c}71(54.2) \\
1(0.8) \\
1(0.8) \\
32(24.4) \\
62(47.3) \\
69(52.7)\end{array}$ \\
\hline
\end{tabular}




\begin{tabular}{|c|c|c|c|c|}
\hline $\begin{array}{l}\text { Domain/ } \\
\text { Diagnosis } \\
\text { (code) }\end{array}$ & Defining characteristics & n (\%) & Related factors & n (\%) \\
\hline $\begin{array}{l}\text { D4/Self- } \\
\text { care deficit } \\
\text { for bathing } \\
(00108)\end{array}$ & $\begin{array}{l}\text { Impaired ability to access the bathroom } \\
\text { Impaired ability to wash the body }\end{array}$ & $\begin{array}{l}17(13.00) \\
95(72.5)\end{array}$ & $\begin{array}{l}\text { Change in cognitive functions } \\
\text { Pain } \\
\text { Musculoskeletal disorders } \\
\text { Neuromuscular diseases }\end{array}$ & $\begin{array}{l}69(52.7) \\
34(25.9) \\
64(48.8) \\
68(51.9)\end{array}$ \\
\hline $\begin{array}{l}\text { D4/Self-care } \\
\text { deficit for } \\
\text { intimate } \\
\text { hygiene } \\
\text { (00110) }\end{array}$ & $\begin{array}{l}\text { Impaired ability to perform intimate hygiene } \\
\text { Impaired ability to reach the toilet } \\
\text { Impaired ability to handle clothes to perform intimate hygiene } \\
\text { Impaired ability to sit on the toilet }\end{array}$ & $\begin{array}{l}94(71.7) \\
3(2.3) \\
1(0.8) \\
1(0.8)\end{array}$ & $\begin{array}{l}\text { Change in cognitive functions } \\
\text { Impaired transfer capacity } \\
\text { Pain } \\
\text { Musculoskeletal disorders } \\
\text { Neuromuscular diseases }\end{array}$ & $\begin{array}{l}68(51.9) \\
85(64.9) \\
28(21.4) \\
56(42.7) \\
59(45.0)\end{array}$ \\
\hline $\begin{array}{l}\text { D4/Self-care } \\
\text { deficit for } \\
\text { dressing } \\
\text { (00109) }\end{array}$ & $\begin{array}{l}\text { Impaired ability to maintain one's physical appearance } \\
\text { Impaired ability to wear each item of clothing item (e.g. shirt, } \\
\text { socks, shoes) } \\
\text { Impaired ability to pick clothing items } \\
\text { Impaired ability to wear lower body clothing items }\end{array}$ & $\begin{array}{l}78(59.5) \\
16(12.2) \\
15(11.4) \\
3(2.3)\end{array}$ & $\begin{array}{l}\text { Change in cognitive functions } \\
\text { Discomfort } \\
\text { Pain } \\
\text { Musculoskeletal disorders } \\
\text { Neuromuscular diseases }\end{array}$ & $\begin{array}{l}70(53.4) \\
1(0.8) \\
35(26.7) \\
65(49.6) \\
71(54.2)\end{array}$ \\
\hline $\begin{array}{l}\text { D4/Impaired } \\
\text { physical } \\
\text { mobility } \\
(00085)\end{array}$ & $\begin{array}{l}\text { Reduction of fine motor skills } \\
\text { Reduction of gross motor skills } \\
\text { Reduction of range of motion } \\
\text { Difficulties to turn around }\end{array}$ & $\begin{array}{l}34(25.9) \\
76(58.0) \\
82(62.6) \\
82(62.6)\end{array}$ & $\begin{array}{l}\text { Change in cognitive functions } \\
\text { Change in the integrity of bone structures } \\
\text { Disuse } \\
\text { Pain } \\
\text { Musculoskeletal disorders } \\
\text { Neuromuscular diseases }\end{array}$ & $\begin{array}{l}65(49.6) \\
52(39.7) \\
39(29.8) \\
26(19.8) \\
58(44.3) \\
67(51.1)\end{array}$ \\
\hline $\begin{array}{l}\text { D4/Impaired } \\
\text { mobility in bed } \\
\text { (00091) }\end{array}$ & $\begin{array}{l}\text { Impaired ability to reposition oneself in bed } \\
\text { Impaired ability to turn from side to side }\end{array}$ & $\begin{array}{l}68(51.9) \\
20(15.3)\end{array}$ & $\begin{array}{l}\text { Change in cognitive functions } \\
\text { Pain } \\
\text { Musculoskeletal disorders } \\
\text { Neuromuscular diseases }\end{array}$ & $\begin{array}{l}62(47.3) \\
26(19.8) \\
44(33.6) \\
51(38.9)\end{array}$ \\
\hline $\begin{array}{l}\text { D5/Impaired } \\
\text { verbal } \\
\text { communication } \\
(00051)\end{array}$ & $\begin{array}{l}\text { Slurred speech } \\
\text { Difficulty to speak } \\
\text { He/she does not speak } \\
\text { Refuses to speak } \\
\text { Improper verbalization } \\
\text { Disorientation towards people } \\
\text { Spatial disorientation } \\
\text { Time disorientation }\end{array}$ & $\begin{aligned} 4 & (3.0) \\
7 & (5.3) \\
51 & (38.9) \\
7 & (5.3) \\
13 & (9.9) \\
12 & (9.2) \\
12 & (9.2) \\
12 & (9.2)\end{aligned}$ & $\begin{array}{l}\text { Change in development } \\
\text { Physical barrier } \\
\text { Physiological condition } \\
\text { Altered perception } \\
\text { Damage to the central nervous system }\end{array}$ & $\begin{array}{c}4(3.0) \\
12(9.2) \\
24(18.3) \\
20(15.3) \\
52(39.7)\end{array}$ \\
\hline $\begin{array}{l}\text { D7/Impaired } \\
\text { social } \\
\text { interaction } \\
(00052)\end{array}$ & Impaired social function & $94(71.7)$ & $\begin{array}{l}\text { Environmental barriers } \\
\text { Communication barriers } \\
\text { Impaired mobility } \\
\text { Disturbed thought processes }\end{array}$ & $\begin{array}{l}89(67.9) \\
60(45.8) \\
85(64.9) \\
17(13.0)\end{array}$ \\
\hline
\end{tabular}

Table 3 - Distribution of the defining characteristics and related factors of the most frequent real nursing diagnoses, identified in patients ( $\mathrm{n}=131)$ in home care, according to NANDA-I taxonomy domains, Montes Claros City, Minas Gerais State, Brazil, from June 2017 to January 2018

\begin{tabular}{|c|c|c|}
\hline Domain/Diagnosis (code) & Risk factors & n (\%) \\
\hline D2/ Risk of electrolyte imbalance (00195) & $\begin{array}{l}\text { Poor volume of liquids } \\
\text { Vomiting } \\
\text { Diarrhea }\end{array}$ & $\begin{array}{c}99(75.6) \\
16(12.2) \\
1(0.8)\end{array}$ \\
\hline D2/ Risk of poor volume of liquids (00028) & $\begin{array}{l}\text { Poor knowledge about needs for liquid intake } \\
\text { Deviations affecting fluid intake } \\
\text { Extremes of age } \\
\text { Barriers to access liquids } \\
\text { Loss of fluid through abnormal passages }\end{array}$ & $\begin{array}{l}50(38.2) \\
35(26.7) \\
71(54.2) \\
72(55.0) \\
17(13.2)\end{array}$ \\
\hline D4/Risk of disuse syndrome (00040) & $\begin{array}{l}\text { Pain } \\
\text { Consciousness level altered } \\
\text { Paralysis }\end{array}$ & $\begin{array}{l}33(25.2) \\
68(51.9) \\
74(56.5)\end{array}$ \\
\hline D11/Risk of pressure ulcers (00249) & $\begin{array}{l}\text { Braden Scale Score }<18 \\
\text { Change in cognitive functions } \\
\text { Change in sensitivity } \\
\text { Dehydration } \\
\text { Extremes of age } \\
\text { Shearing forces } \\
\text { Feminine gender } \\
\text { History of stroke } \\
\text { History of trauma } \\
\text { History of pressure ulcer } \\
\text { Pressure on bone prominence } \\
\text { Reduction in mobility }\end{array}$ & $\begin{array}{l}85(64.9) \\
65(49.6) \\
54(41.2) \\
22(16.8) \\
65(49.6) \\
99(75.6) \\
62(47.3) \\
30(22.9) \\
18(11.4) \\
60(45.8) \\
64(48.8) \\
99(75.6)\end{array}$ \\
\hline
\end{tabular}




\section{DISCUSSION}

From data analysis, there were 49 different diagnostic titles. Of these, $36(73.5 \%)$ refer to real NDs and $13(26.5 \%)$ to risk diagnosis titles. This is a significant profile of NDs, given nursing care planning should focus first on real NDs. Risk NDs must be identified and interventions must be implemented with the aim of preventing complications and preserving patient safety ${ }^{(13)}$.

The mean age was 66.8 years; among the individuals, $55 \%$ were female and the highest prevalence was of circulatory system diseases. These data are corroborated by other international studies ${ }^{(6-9)}$. Globally, demographic and epidemiological changes have taken place, and Brazil follows these trends, such as the increase in the number of elderly people and the phenomenon of feminization of aging, due to women's longer life expectancy ${ }^{(14-15)}$. We also highlight circulatory system diseases as the major global health problem ${ }^{(16)}$.

Within the field of Nutrition, diagnoses identified as more frequent were: Risk of poor volume of liquids, evidenced mainly by insufficient fluid volume; and the Risk of electrolyte imbalance, with emphasis on extreme risk factors of age and barrier to access to liquids. These diagnoses were identified in a study with patients in home care in Spain ${ }^{(9)}$.

The Risk of poor volume of liquids and the Risk of electrolyte imbalance may result from the aging process, since physiological changes contribute to its occurrence, such as the reduction of the thirst mechanism and the regulation of water losses ${ }^{(17)}$. In addition, there are barriers that make it difficult to access and limitations to the intake of related liquids, for example, the patient's clinic can make it impossible to verbalize thirst.

In the Elimination and change domain, the diagnosis of impaired urinary elimination was identified, which was related to multiple causes and evidenced by the defining feature of urinary incontinence. Like other studies ${ }^{(6-8)}$, this diagnosis was commonly found in patients in $\mathrm{HC}$. In these patients, changes in the genitourinary system are relevant ${ }^{(18)}$. In addition, changes due to the aging process ${ }^{(19)}$, which increase the vulnerability to the development of ND, are associated with Impaired urinary elimination.

The Activity/rest domain was the one that presented the highest frequency of ND titles, and the most prevalent diagnosis was Impaired physical mobility, for which the most recurrent factors were neuromuscular impairment and altered cognitive function, and defining characteristics: reduction in range of motion, difficulty to turn around and reduction in gross motor skills. This domain and diagnosis were also identified with prevalence in other studies ${ }^{(6-9)}$, with patients with a similar profile.

This ND may be associated with the clinical conditions usually identified in $\mathrm{HC}$ patients, such as progression of neurodegenerative or cerebrovascular diseases, trauma sequelae caused by urban violence or in traffic, frailty and dementia syndromes ${ }^{(18)}$.

It is also noteworthy, in the referred field, are the NDs related to Self-care deficit, defined as the impaired ability to perform or complete feeding, bathing/hygiene, intimate hygiene, or dressing activities. Like other studies ${ }^{(6-9)}$, the identification of these NDs demonstrates the dependency of home patients for Basic Activities of Daily Living (ADLs) ${ }^{(20)}$.

In the Perception/cognition domain, the most frequent ND was impaired verbal communication, related particularly to impairment in the central nervous system characterized by inability to speak. In previous studies ${ }^{(7,9)}$ this is a common ND. In the present study, impaired verbal communication was identified in patients with dementia, brain neoplasia, cerebral palsy, traumatic brain injury, amyotrophic lateral sclerosis, Parkinson's disease and, most notably, stroke.

In a study ${ }^{(21)}$, which evaluated the ND of impaired verbal communication, specifically in patients who suffered stroke, the prevalence was $37.5 \%$. Changes in communication, mainly in verbal communication, require special nursing attention, which should focus on caregiving actions that consider the difficulty or inability of the person to express their needs ${ }^{(22)}$.

In the Roles and Relationships domain, impaired social interaction ND was the most frequent one, with predominant factors characterized by impaired mobility, environmental barriers and barriers of communication, evidenced by impaired social function. The conditions presented by patients in home care suggest that undesirable human responses go beyond biomedical or physiological issues, indicating that nurses must understand and care for patients in biopsychosocial and spiritual perspectives.

In the Safety/protection domain, the main ND was the risk of pressure ulcers, with the most frequent risk factors being shear forces, reduced mobility, Braden Scale $<18$, altered cognitive function and pressure on bone prominence. It is emphasized that in previous studies ${ }^{(6-9)}$ on the topic, this ND was not identified because previous editions of NANDA-I were used, and ND was added in the 2015-2017 edition. Due to the different risk factors to which $\mathrm{HC}$ patients are exposed and because it is a high prevalence (79.4\%) that can result in severe complications, it is essential that nurses implement prevention actions and monitor this problem.

Results show that, due to the clinical profile of patients, there is a varied prevalence of NDs, mainly related to NANDA-I, Activity/ rest, Safety/protection and Elimination and change domains. However, we have not identified NDs in the domains of human responses to Sexuality and Growth/Development. This finding is similar in studies ${ }^{(6-9)}$ on the subject and in others ${ }^{(5,13,23)}$ that identified NDs in different clinical profiles and settings.

It is important to highlight lack of training and difficulty of health professionals when dealing with issues of sexuality. The result demonstrates the need to foster discussion on the subject during academic training and reinforces the conception of reorientation of care to a perspective in which the various domains of human responses are addressed.

The change in cognitive functions present as a related factor to the majority of the most frequent real NDs is highlighted. In addition to clinical conditions (dementia, brain neoplasia, cerebral palsy, traumatic brain injury, Parkinson's and stroke) characteristics of HC patients, one study ${ }^{(24)}$ states that, mainly in the elderly, cognitive changes are related to the development of fragility and consequent dependence.

Many are undesired human responses in $\mathrm{HC}$ patients. The identification of NDs profiles, incorporated to a standardized language system, helps with care management, as well as with organizational processes.

\section{Study limitations}

The study has some limitations. It is derived from a crosssectional study, and it is not possible to investigate conditions 
of low prevalence, feasible in longitudinal studies. Sample losses increased the proportion of non-responses. It is highlighted that there is a shortage of national and international literature, and studies that worked with similar profiles did not determine the related factors, risk factors and defining characteristics. Therefore, it cannot be inferred that the results found in this study are totally equivalent to the existing literature. However, despite these limitations, the study has enough methodological rigor to mitigate or eliminate biases.

\section{Contributions to the Nursing, Health or Public Policy Areas}

Differently from previous international studies on ND in HC patients, the present study, in addition to the titles of nursing diagnoses, identified related factors, risk factors and defining characteristics. The identification of the set of phenomena favors the planning and implementation of accurate interventions to prevent or solve problems and promote the health of patients in home care, avoiding adverse clinical outcomes.
The profile of ND found may contribute to the consolidation of the identity, visibility, professional autonomy and elucidation of the scope of Nursing knowledge in home care.

\section{CONCLUSION}

This study allowed us to identify the clinical situations that can be used in nursing interventions and to verify their equivalence with 49 NANDA-I nursing diagnostic titles. Considering the domains, the most frequent diagnoses were: risk of poor fluid volume; risk of electrolyte imbalance; impaired urinary elimination; impaired physical mobility; impaired verbal communication; impaired social interaction; and risk of pressure ulcers.

The characterization of the diagnosis profile, in addition to clearly and concisely describing real and potential problems, contributes to patient care, language standardization, information documentation, generation of indicators sensitive to Nursing practice and facilitates communication among nurses and other health professionals.

\section{REFERENCES}

1. Ministério da Saúde (BR), Gabinete do Ministro. Portaria n 825, de 25 de abril de 2016. Redefine a Atenção Domiciliar no âmbito do Sistema Único de Saúde (SUS) e atualiza as equipes habilitadas [Internet]. Diário Oficial da União: República Federativa do Brasil; 2016 [cited 2019 Mar 10]. Apr 25. Seção 1: [about 19 screens]. Available from: http://bvsms.saude.gov.br/bvs/saudelegis/gm/2016/prt0825_25_04_2016.html

2. Andrade AM, Silva KL, Seixas CT, Braga PP. Nursing practice in home care: an integrative literature review. Rev Bras Enferm [Internet]. 2017[cited 2018 Apr 25];70(1):199-208. Available from: http://www.scielo.br/pdf/reben/v70n1/en_0034-7167-reben-70-01-0210.pdf

3. Conselho Federal de Enfermagem (BR). Resolução № 358 do Conselho Federal de Enfermagem, de 15 de outubro de 2009 [Internet]. Brasília; 2009 [cited 2018 Mar 16]. Available from: http://www.cofen.gov.br/resoluo-cofen-3582009_4384.html

4. Herdman TH, Kamitsuru S. Diagnósticos de enfermagem da NANDA: definições e classificação 2015-2017. Porto Alegre: Artmed; 2015.

5. Ferreira AM, Rocha EN, Lopes CT, Bachion MM, Lopes JL, Barros ALBL. Nursing diagnoses in intensive care: cross-mapping and NANDA-I taxonomy. Rev Bras Enferm [Internet]. 2016[cited 2018 Apr 25];69(2):285-93. Available from: http://www.scielo.br/pdf/reben/v69n2/ en_0034-7167-reben-69-02-0307.pdf

6. Zink MR. Nursing diagnosis in home care: audit tool development. J Community Health Nurs [Internet]. 1994 [cited 2018 Apr 25];11(1):51-8. Available from: https://doi.org/10.1207/s15327655jchn1101_6

7. Lee TT, Mills ME. The relationship among medical diagnosis, nursing diagnosis, and nursing intervention and the implications for home health care. J Prof Nurs [Internet]. 2000 [cited 2018 Apr 25];16(2):84-91. Available from: https://www.ncbi.nlm.nih.gov/pubmed/10748569

8. Keenan G, Stocker J, Barkauskas V, Treder M, Heath C. Toward integrating a common nursing data set in home care to facilitate monitoring outcomes across settings. J Nurs Meas [Internet]. 2003 [cited 2018 Apr 25];7(2):74-83. Available from: https://www.ncbi.nlm.nih.gov/ pubmed/15274523

9. Asencio JMM, Herrera JCM, Santos FJM, Jimenez EG, Gallego MCF, Nieves CB, et al. The association between nursing diagnoses, resource utilisation and patient and caregiver outcomes in a nurse-led home care service: Longitudinal study. Int J Nurs Stud [Internet]. 2009 [cited 2018 Apr 25];46(2):189-96. Available from: https://www.ncbi.nlm.nih.gov/pubmed/18990392

10. Horta WA. Processo de Enfermagem. Rio de Janeiro: Guanabara Koogan; 2011.

11. Tannure MC, Salgado PO, Chianca TCM. Mapeamento cruzado: títulos diagnósticos formulados segundo a CIPE" versus diagnósticos da NANDA Internacional. Rev Bras Enferm [Internet]. 2014[cited 2018 Apr 25];67(6):972-8. Available from: http://www.scielo.br/pdf/reben/ v67n6/0034-7167-reben-67-06-0972.pdf

12. Carvalho EC, Cruz DALM, Herdman TH. Contribuição das linguagens padronizadas para a produção do conhecimento, raciocínio clinico e prática clínica da Enfermagem. Rev Bras Enferm [Internet]. 2013 [cited 2018 Apr 25];66(esp):134-41. Available from: http://www.scielo.br/ pdf/reben/v66nspe/v66nspea17.pdf

13. Araújo DD, Carvalho RLR, Chianca TCM. Nursing diagnoses identified in records of hospitalized elderly. Invest Educ Enferm [Internet]. 2014 [cited Apr 25 2018];32(2):225-35. Available from: http://www.scielo.org.co/pdf/iee/v32n2/v32n2a05.pdf

14. Silva PAB, Santos FC, Soares SM, Silva LB. Sociodemographic and clinical profile of elderly persons accompanied by Family Health teams under the gender perspective. Rev Fund Care [Internet]. 2018[cited Apr 25 2018];10(1):97-105. Available from: http://seer.unirio.br/index. 
php/cuidadofundamental/article/view/5987/pdf

15. United Nations, Department of Economic and Social Affairs, Population Division. The World Population Situation in 2014 [Internet]. New York: United Nations; 2014 [cited 2019 Mar 10]. 2 p. Available from: http://www.un.org/en/development/desa/population/events/pdf/ other/4/World\%20Population\%20Situation_2014_10\%20key\%20findings_en.pdf

16. GBD 2015 DALYs, HALE Collaborators. Global, regional, and national disability-adjusted life-years (DALYs) for 315 diseases and injuries and healthy life expectancy (HALE), 1990-2015: a systematic analysis for the Global Burden of Disease Study 2015. Lancet [Internet]. 2016 [cited Apr 25 2018];388(10053):1603-58. Available from: https://www.ncbi.nlm.nih.gov/pmc/articles/PMC5388857/pdf/main.pdf

17. Clares JWB, Freitas MC. Diagnósticos de enfermagem do domínio nutrição identificados em idosos da comunidade. Rev Eletr Enf [Internet]. 2013[cited Apr 25 2018];15(4):940-7. Available from: https://revistas.ufg.br/fen/article/view/20513/15714

18. Ministério da Saúde (BR), Secretaria de Atenção à Saúde, Departamento de Atenção Básica. Caderno de atenção domiciliar [Internet]. Brasília: Ministério da Saúde, 2013 [cited 2019 Mar 10]. 106 p. Available from: http://189.28.128.100/dab/docs/publicacoes/geral/cad_vol1.pdf

19. Bitencourt GR, Felippe NHM, Santana RF. Nursing diagnoses of impaired urinary elimination in hospitalized, post-operative elderly: a crosssectional study. Rev Enferm UERJ [Internet]. 2016[cited Apr 25 2018];24(3):e16629. Available from: http://www.e-publicacoes.uerj.br/index. php/enfermagemuerj/article/view/16629/23274

20. Santos AC, Silva JOM, Makuch DMV, Matia G, Rozin L. Sobrecarga do cuidador familiar do idoso dependente. Rev Saúde Pública Paraná [Internet]. 2017 [cited 2018 Apr 22];18(2):55-62. Available from: https://doi.org/10.22421/1517-7130.2017v18n2p55

21. Chaves DBR, Costa AGS, Oliveira ARS, Silva VM, Araújo TL, Lopes MVO. Comunicação verbal prejudicada - investigação no período pósacidente vascular encefálico. Rev RENE [Internet]. 2013[cited 2018 Apr 22];14(5):877-85. Available from: http://www.periodicos.ufc.br/rene/ article/view/3608/2849

22. Lima ACMACC, Silva AL, Guerra DR, Barbosa IV, Bezerra KC, Oriá MOB. Nursing diagnoses in patients with cerebral vascular accident: an integrative review. Rev Bras Enferm [Internet]. 2016[cited 2018 Apr 22];69(4):738-45. Available from: http://www.scielo.br/pdf/reben/v69n4/ en_0034-7167-reben-69-04-0785.pdf

23. D’Agostino F, Zeffiro V, Vellone E, Ausili D, Belsito R, Leto A, et al. Cross-Mapping of Nursing Care Terms Recorded in Italian Hospitals into the Standardized NNN Terminology. Int J Nurs Knowl [Internet]. 2018 [cited Apr 25 2018]; 00(0):1-10. Available from: https://doi. org/10.1111/2047-3095.12200

24. Brigola AG, Rossetti ES, Santos BR, Neri AL, Zazzetta MS, Inouy K, et al. Relationship between cognition and frailty in elderly: A systematic review. Dement Neuropsychol [Internet]. 2015[cited 2018 Apr 22];9(2):110-9. Available from: http://www.scielo.br/pdf/dn/v9n2/1980-5764dn-09-02-00110.pdf 